Acta Horticulturae et Regiotecturae 1

Nitra, Slovaca Universitas Agriculturae Nitriae, 2020, pp. 56-59

\title{
GENETIC ANALYSIS OF SOME AGRONOMIC TRAITS IN OKRA (ABELMOSCHUS ESCULENTUS L. [MOENCH])
}

\author{
Muyideen Oluseyi OLAYIWOLA ${ }^{2 *}$, Deborah Doyinsola OLANIRAN ${ }^{1}$, \\ Adesola Lateef NASSIR ${ }^{2}$, Omolayo Johnson Ariyo ${ }^{1,2}$ \\ ${ }^{1}$ Olabisi Onabanjo University, Ago-Iwoye, Nigeria \\ ${ }^{2}$ Federal University of Agriculture Abeokuta, Nigeria
}

\begin{abstract}
A study was carried out at the Federal University of Agriculture Abeokuta, Nigeria to determine the gene action underlying the inheritance of important agronomic traits as well as the general combining ability (GCA) and specific combining ability (SCA) of the parents and hybrids, respectively. Ten hybrids were developed by crossing five lines to two testers. The hybrids and parents were evaluated on the field in a randomised complete block design replicated three times, and data were collected on days to $50 \%$ flowering, number of branches, stem diameter, plant height, pod length, pod width, pod weight, number of pods and pod yield. The data were subjected to line by tester analysis and results showed substantial variability among the genotypes for some of the characters measured. Days to $50 \%$ flowering, number of pods and pod yield were largely under additive gene action while non-additive gene action was more important in the inheritance of plant height. Favourable GCA and SCA effects for days to $50 \%$ flowering were observed in NGB00356, NGB00326 and NGB00347 × NGB00326, respectively. The tester NGB00326 had a positive and significant GCA effect for number of pods while the highest positive SCA effect for pod yield was found in NGB00297 $\times$ NGB00326. Thus, NGB00356 and NGB00326 could be considered as sources of alleles for development of early maturing while the cross NGB00297 $\times$ NGB00326 could be exploited for high yielding okra genotypes.
\end{abstract}

Keywords: earliness, high yielding, hybrids, okra

Okra (Abelmoschus esculentus L. [Moench]) is an important vegetable crop in West and Central Africa (Nwangburuka et al., 2012), where it is referred to as "a perfect villager's vegetable" due to the high dietary fibre and seed protein balance it offers in diets (Kumar et al., 2010). However, low yields have been recorded on farmers' fields due to the lack of adapted genotypes, narrow genetic base of existing cultivars and unpredictable length of the growing season (Ahiakpa et al., 2013). It is vital to develop okra varieties with early maturing and high yielding potentials. Arora et al. (2007) noted that these traits were polygenic and their expression greatly influenced by the environmental fluctuations. They submitted that an understanding of the gene action that controls the inheritance of fruit yield and earliness related traits in okra was important.

Line $\times$ Tester analysis proposed by Kempthorne (1957) is a popular mating design among plant breeders and its efficiency in detecting the nature and magnitude of gene action controlling important agronomic traits in crops has been reported (Prakash et al., 2002). Furthermore, line $x$ tester analysis provides estimates of specific combining ability (SCA) of each cross and general combining ability (GCA) of lines and testers and at the same time, it is helpful in estimating various types of gene actions that are important in the expression of quantitative traits (Rashid et al., 2007).
The technique thus aids the identification of potential parents for hybridization based on genetic information and knowledge of their combining ability.

Different workers have carried out combining ability studies in okra with different outcomes. Shusmita and Das (2003) reported that additive gene action was more important in the inheritance of inter-node length, number of nodes, fruit length, fruit diameter, plant height and pod yield. Kumar (2006), however, noted that non-additive gene action was largely responsible for the expression of plant height, number of branches, pod weight, pod length and pod yield. Rewale et al. (2003) in their study identified three lines; DVR-4, SOH-02 and Arka Anamika that had favourable GCA effects for yield and related traits. Prakash et al., (2002) in a line $\times$ tester analysis involving 7 lines and 3 testers reported the preponderance of non-additive gene action over additive gene action for all the measured traits. They further identified 4 out of 10 parents with good GCA for pod yield while 2 of the 21 hybrids exhibited favourable SCA effects for the majority of the characters.

The objectives of this study were to determine the gene action controlling the inheritance of some important agronomic traits in okra and to determine the combining ability of the parents used in the study.

Contact address: Muyideen Oluseyi Olayiwola, Olabisi Onabanjo University, College of Agricultural Sciences, Department of Crop Production, Ago-iwoye, Nigeria, Phone: +2348033990585, e-mail: ollyrichie@gmail.com; muyideen.olayiwola@ oouagoiwoye.edu.ng; 


\section{Materials and methods}

\section{Planting materials and generation of hybrids}

The study was carried out at the Teaching and Research Farm of the Federal University of Agriculture, Abeokuta, Nigeria (latitude $7^{\circ} 29^{\prime} \mathrm{N}$ and longitude $3^{\circ} 3^{\prime} \mathrm{E}$ ). Seven inbred lines sourced from the gene bank of the National Centre for Genetic Resources and Biotechnology (NACGRAB), Ibadan, were utilised for this study. Five were designated as lines and two as testers based on their previous performance (Oyetunde, 2015). Each male (Tester) parent was crossed to each female (Line) parent to generate ten crosses. Each genotype was sown in single row plot of $4 \mathrm{~m}$ length with $0.6 \mathrm{~m}$ as inter-row and $0.4 \mathrm{~m}$ as intra-row. Planting was done in succession to ensure synchronization of flowering, and crosses were made accordingly. The parents were selfed to ensure availability of fresh seeds for evaluation. Harvesting was done after the pods had dried on the mother plants to ensure viability of seeds for evaluation.

\section{Field evaluation and data collection}

The ten hybrids and seven parents were sown at the rate of two seeds per hole and later thinned to one plant per stand.
The experiment was laid out in a randomized complete block design (RCBD) with three replications separated by $1 \mathrm{~m}$ to enhance easy movement during field operations. Each plot was a $4.5 \mathrm{~m}$ long single row with $0.70 \mathrm{~m}$ as inter-row and $0.45 \mathrm{~m}$ as intra-row. Three and six weeks after planting, NPK $15: 15: 15$ was applied at a recommended rate of $60 \mathrm{kgN}$. $\mathrm{ha}^{-1}$ using the side placement method. Weeding was done manually as necessary and insect pests were controlled using cypermethrin at the rate of $4 \mathrm{ml}^{\text {.litre }}{ }^{-1}$ of water.

Observations were made on number of days to $50 \%$ flowering, plant height $(\mathrm{cm})$, stem diameter $(\mathrm{cm})$, number of branches, number of pods, pod weight (g), pod length $(\mathrm{cm})$, pod width $(\mathrm{cm})$ and pod yield $(\mathrm{kg})$ from representative plants on each plot.

\section{Data analysis}

Data collected were subjected to line $x$ tester analysis as described by Singh and Chaudhary (1985) to determine the gene action underlying the inheritance of the measured characters. The GCA and SCA and their corresponding standard errors were then computed for all traits. The two genetic parameters were tested for significance using their standard errors as outlined by Singh and Chaudhary (1985).

Table 1 Mean squares from ANOVA of characters evaluated in okra using line by tester analysis

\begin{tabular}{|l||c|c|c|c|c|c|c|c|c|}
\hline Source & Df & $\mathbf{5 0 \% F ^ { \mathbf { a } }}$ & $\mathbf{N o B}$ & $\mathbf{S t G}$ & $\mathbf{P t H}$ & $\mathbf{P d L}$ & PdWgt & NPdPt & YPt \\
\hline Replicate & 2 & 31.82 & 7.19 & $0.59^{* *}$ & $1652.93^{*}$ & 0.13 & 0.03 & $291.25^{* *}$ & $59627.83^{* *}$ \\
\hline Genotype & 16 & $126.81^{* *}$ & 3.44 & 0.1 & $1955.48^{* *}$ & $0.94^{* *}$ & 2.29 & $68.59^{* *}$ & 6840.68 \\
\hline Parent (P) & 6 & $122.65^{* *}$ & 2.82 & 0.05 & $1562.86^{* *}$ & 1.54 & 3.68 & $92.95^{* *}$ & $7277.42^{* *}$ \\
\hline Cross (C) & 9 & $88.46^{* *}$ & 3.1 & 0.04 & $937.29^{* *}$ & 0.61 & 1.62 & $56.56^{* *}$ & $4765.63^{* *}$ \\
\hline PvsC & 1 & $496.98^{* *}$ & 10.18 & 0.94 & $13474.88^{* *}$ & 0.21 & 0.02 & 30.74 & $22895.76^{* *}$ \\
\hline Line (L) & 4 & $81.45^{* *}$ & 1.1 & 0.02 & $813.69^{* *}$ & 0.9 & 2.38 & 32.06 & $1849.19^{* *}$ \\
\hline Tester (T) & 1 & $202.80^{* *}$ & 7.7 & 0.04 & $329.35^{* *}$ & 1.01 & 1.88 & $339.36^{* *}$ & $29371.92^{* *}$ \\
\hline L $\times \mathbf{T}$ & 4 & $66.88^{*}$ & 3.95 & 0.06 & $1212.88^{* *}$ & 0.23 & 0.79 & 10.35 & $1530.49^{* *}$ \\
\hline Error & 32 & 17.99 & 2.7 & 0.05 & 626.82 & 0.17 & 2.24 & 23.37 & 4089.23 \\
\hline
\end{tabular}

Table 2 General combining ability (GCA) of the parental lines evaluated for 8 agronomic traits in okra

\begin{tabular}{|c|c|c|c|c|c|c|c|c|}
\hline Line & $50 \% F^{a}$ & NoB & StG & PtH & PdL & PdWdt & NPdPt & YPt \\
\hline NGB00303 & $4.13^{*}$ & 0.49 & 0.03 & 12.64 & $-0.50^{* *}$ & 0.03 & -0.76 & -4.36 \\
\hline NGB00346 & 2.8 & -0.53 & 0.08 & 5.27 & $-0.28^{*}$ & 0 & -1.58 & -10.92 \\
\hline NGB00347 & 0.3 & -0.03 & -0.08 & -13.25 & $0.35^{*}$ & -0.07 & -2.53 & -24.86 \\
\hline NGB00297 & -2.37 & -0.29 & -0.01 & 6.85 & 0.05 & $0.08^{*}$ & 2.34 & 36.83 \\
\hline NGB00356 & $-4.87^{* *}$ & 0.36 & -0.02 & -11.51 & $0.38^{*}$ & -0.04 & 2.54 & 3.32 \\
\hline SE line & 1.73 & 0.67 & 0.09 & 10.22 & 0.17 & 0.05 & 1.97 & 34.90 \\
\hline \multicolumn{9}{|c|}{ Tester } \\
\hline NGB00326 & $-2.60^{*}$ & 0.51 & 0.04 & -3.31 & $0.18^{*}$ & -0.02 & $3.36^{* *}$ & 41.06 \\
\hline NGB00302 & $2.60^{*}$ & -0.51 & -0.04 & 3.31 & $-0.18^{*}$ & 0.02 & $-3.36^{* *}$ & -41.06 \\
\hline SE tester & 1.1 & 0.42 & 0.06 & 6.46 & 0.11 & 0.03 & 1.25 & 21.66 \\
\hline
\end{tabular}

(for tables 1 and 2 ) ${ }^{* * * *}$ significant at 5 and $1 \%$ probability levels, respectively

$50 \% \mathrm{Fa}$ - days to $50 \%$ flowering, NoB - number of branches, StG - stem diameter (cm), PtH - plant height $(\mathrm{cm}), \mathrm{PdL}$ - pod length (cm), PdWdt - pod width (cm), PdWgt - pod weight (g), NPdPt - number of pods, YPt - pod yield $\left(\mathrm{kg}^{\circ} \cdot \mathrm{ha}^{-1}\right)$ 
Table 3 Specific combining ability (SCA) effects of 10 hybrids evaluated for 8 agronomic traits in okra

\begin{tabular}{|c|c|c|c|c|c|c|c|c|}
\hline Cross & $50 \% F^{a}$ & NoB & StG & PtH & PdL & PdWdt & NPdPt & YPt \\
\hline NGB00303 × NGB00326 & 0.93 & 0.41 & 0.1 & 19.16 & -0.2 & 0.02 & -0.4 & 24.60 \\
\hline NGB00303 $\times$ NGB00302 & -0.93 & -0.41 & -0.1 & -19.16 & 0.2 & -0.02 & 0.4 & -24.60 \\
\hline NGB00346 × NGB00326 & 1.93 & 0.83 & -0.07 & -6 & -0.18 & 0.02 & 0.15 & -7.56 \\
\hline NGB00346 × NGB00302 & -1.93 & -0.83 & 0.07 & 6 & 0.18 & -0.02 & -0.15 & 7.56 \\
\hline NGB00347 × NGB00326 & $-4.23^{*}$ & -1.01 & -0.04 & 0.21 & 0.25 & -0.08 & 0.34 & -12.88 \\
\hline NGB00347 × NGB00302 & $4.23 *$ & 1.01 & 0.04 & -0.21 & -0.25 & 0.08 & -0.34 & 12.88 \\
\hline NGB00297 × NGB00326 & -2.57 & 0.49 & -0.09 & -19.25 & 0.12 & 0.01 & 1.77 & 19.37 \\
\hline NGB00297 × NGB00302 & 2.57 & -0.49 & 0.09 & 19.25 & -0.12 & -0.01 & -1.77 & -19.37 \\
\hline NGB00356 × NGB00326 & 3.93 & -0.72 & 0.11 & 5.88 & 0.02 & 0.02 & -1.86 & -23.55 \\
\hline NGB00356 × NGB00302 & -3.93 & 0.72 & -0.11 & -5.88 & -0.02 & -0.02 & 1.86 & 23.55 \\
\hline SE (LXT) & 2.45 & 0.95 & 0.13 & 14.45 & 0.24 & 0.07 & 2.79 & 48.46 \\
\hline
\end{tabular}

**** significant at 5 and $1 \%$ probability levels, respectively.

$50 \% \mathrm{~F}^{\mathrm{a}}$ - days to $50 \%$ flowering, $\mathrm{NoB}$ - number of branches, $\mathrm{StG}$ - stem diameter $(\mathrm{cm}), \mathrm{PtH}$ - plant height $(\mathrm{cm}), \mathrm{PdL}$ - pod length $(\mathrm{cm})$, PdWdt - pod width (cm), PdWgt - pod weight $(\mathrm{g}), \mathrm{NPdPt}$ - number of pods, $\mathrm{YPt}$ - pod yield $\left(\mathrm{kg}^{\mathrm{h}} \mathrm{ha}^{-1}\right)$

Table 4 Mean performance of the 17 okra genotypes evaluated for eight agronomic traits

\begin{tabular}{|c|c|c|c|c|c|c|c|c|c|}
\hline Genotype & $50 \% F^{a}$ & NoB & StG & PtH & PdL & PdWdt & PdWgt & NPdPt & Ypt \\
\hline NGB00326 (T1) & 68.33 & 6.87 & 1.46 & 143.43 & 5.30 & 1.93 & 8.77 & 20.23 & 803.45 \\
\hline NGB00302 (T2) & 70.00 & 5.73 & 1.45 & 136.87 & 4.33 & 2.37 & 11.17 & 10.10 & 504.45 \\
\hline NGB00303 (L1) & 56.33 & 5.90 & 1.22 & 129.07 & 5.93 & 2.13 & 12.07 & 25.47 & 1115.69 \\
\hline NGB00346 (L2) & 55.67 & 6.87 & 1.16 & 103.30 & 5.47 & 2.27 & 11.10 & 21.13 & 889.44 \\
\hline NGB00347 (L3) & 56.00 & 7.90 & 1.37 & 146.37 & 6.47 & 1.90 & 10.60 & 25.63 & 847.61 \\
\hline NGB00297 (L4) & 55.67 & 5.40 & 1.38 & 87.37 & 5.50 & 2.13 & 9.77 & 26.10 & 1100.94 \\
\hline NGB00356 (L5) & 57.00 & 7.67 & 1.49 & 106.10 & 6.30 & 2.00 & 11.40 & 21.97 & 896.53 \\
\hline NGB00303 × NGB00326 (L1×T1) & 68.67 & 8.93 & 1.81 & 183.30 & 4.97 & 2.20 & 9.07 & 25.30 & 1253.73 \\
\hline NGB00346 × NGB00326 (L2×T1) & 68.33 & 8.33 & 1.68 & 150.77 & 5.20 & 2.17 & 10.20 & 25.03 & 1130.82 \\
\hline NGB00347 × NGB00326 $(\mathrm{L} 3 \times \mathrm{T} 1)$ & 59.67 & 7.00 & 1.56 & 138.47 & 6.27 & 2.00 & 10.50 & 24.27 & 1069.69 \\
\hline NGB00297 × NGB00326 $($ L4 × T1) & 58.67 & 8.23 & 1.57 & 139.10 & 5.83 & 2.23 & 11.50 & 30.57 & 1367.89 \\
\hline NGB00356 × NGB00326 (L5 ×T1) & 62.67 & 7.67 & 1.76 & 145.87 & 6.07 & 2.13 & 11.17 & 27.13 & 1125.27 \\
\hline NGB00303 $\times$ NGB00302 $($ L1 $\times$ T2 $)$ & 72.00 & 7.10 & 1.53 & 151.60 & 5.00 & 2.20 & 10.73 & 19.37 & 836.78 \\
\hline NGB00346 $\times$ NGB00302 $(L 2 \times$ T2 $)$ & 69.67 & 5.67 & 1.76 & 169.40 & 5.20 & 2.17 & 10.90 & 18.00 & 918.03 \\
\hline NGB00347 × NGB00302 (L3 × T2) & 73.33 & 8.00 & 1.56 & 144.67 & 5.40 & 2.20 & 10.67 & 16.87 & 890.69 \\
\hline NGB00297 × NGB00302 (L4 × T2) & 69.00 & 6.23 & 1.68 & 184.23 & 5.23 & 2.27 & 11.67 & 20.30 & 984.15 \\
\hline NGB00356 ×NGB00302 (L5 × T2) & 60.00 & 8.10 & 1.47 & 140.73 & 5.67 & 2.13 & 10.97 & 24.13 & 1014.03 \\
\hline Mean & 63.59 & 7.15 & 1.52 & 141.21 & 5.54 & 2.14 & 10.72 & 22.45 & 985.25 \\
\hline SE & 1.58 & 0.26 & 0.04 & 6.19 & 0.14 & 0.03 & 0.21 & 1.16 & 48.16 \\
\hline
\end{tabular}

$50 \% \mathrm{Fa}$ - days to $50 \%$ flowering, NoB - number of branches, StG - stem diameter $(\mathrm{cm}), \mathrm{PtH}$ - plant height $(\mathrm{cm}), \mathrm{PdL}$ - pod length $(\mathrm{cm})$, PdWdt - pod width $(\mathrm{cm})$, PdWgt - pod weight $(\mathrm{g}), \mathrm{NPdPt}$ - number of pods, YPt - pod yield $\left(\mathrm{kg}^{\mathrm{h}} \cdot \mathrm{ha}^{-1}\right)$

\section{Results and Discussion}

A detailed understanding of the inheritance of important agronomic traits in okra is central to the improvement of the vegetable crop. Identification of ideal parents, development and promotion of hybrids would not only increase yields, but also serve as sustainable sources of useful genetic variability for continuous improvement program. Hybridization between genotypes that are not genetically diverse or with little genetic variation might not give higher heterotic value in $\mathrm{F}_{1}$ and may result in narrow range of variability in the segregating $F_{2}$ population. The significant differences revealed among the genotypes for 
days to flowering, plant height, pod length and number of pods (Table 1) underscored the differential performance among the parents and their hybrids which is an indication of substantial genetic variability that could be explored for future improvement (Weeraskar, 2006).

A significant line or tester and line $x$ tester effects on a trait is an indication of the gene action conditioning the trait under consideration and the worth of the parents and hybrids for that trait. For instance, a significant line or tester effect implies that such trait is under additive gene control while a significant line $\times$ tester effect suggests that the character is under non-additive gene control. When both are significant, that is, line/tester and line $\times$ tester, the effect with the highest mean square would be considered more important in the inheritance of the concerned trait. In our study, line or tester and line $\times$ tester effects were significant for days to $50 \%$ flowering, plant height and pod yield which implies that breeding strategies that could take advantage of both additive and non-additive gene effects should be considered in the improvement of the traits listed. However, based on the components of mean squares, additive gene action is more important than non additive in the control of earliness and pod yield implying that faster progress may be obtained through recurrent selection scheme. Plant height would be best improved through heterotic breeding as suggested by the higher importance of non-additive gene action in its inheritance.

Secondly, the significant tester effect for some of the evaluated characters confirmed the contrasting nature of NGB00326 and NGB00302 that were used as testers in this study. This implies that the testers have the potential to discriminate among the lines in terms of the values for the measured traits. That the line had significant effect on some traits indicated that the lines showed varied performance (GCA) in hybrid combinations with the testers while the significant line $\times$ tester effect points to differential performance of specific crosses. Furthermore, the parents and crosses that showed significant combining ability effects in the preferred direction are high combiners and valuable sources of favourable alleles for the improvement of the character involved (Reddy et al., 2013; Badu-Apraku et al., 2016). For instance, the negative significant GCA effect associated with NGB00356 and NGB00326 (Table 2) for days to $50 \%$ flowering shows the worth of this line in the development of early maturing okra genotypes. Tester NGB00326 had a positive and significant GCA effect for number of pods indicating its value as a candidate parent in the development of high yielding okra genotypes (Prakash et al., 2002; Rewale et al., 2003).

All the hybrids showed non-significant SCA effects (Table 3) for all characters except days to $50 \%$ flowering in hybrids NGB00347 × NGB00326 (earliness) and NGB00347 × NGB00302 (late maturity). This may be due to the lack of complementation of the parental genes and/or because okra is a self-pollinated crop, leading to little heterotic advantage. Reddy et al., (2013) had earlier reported that self-pollinated crops such as okra exhibit low hybrid vigour. However, NGB00297 × NGB00326 had the highest positive SCA effect for pod yield and also the highest pod yield (Table 4). Thus, NGB00356 and NGB00326 could be considered as sources of alleles for the development of early maturing okra types while the cross NGB00297 × NGB00326 could be exploited for production of high yielding okra genotypes.

\section{Conclusion}

The study revealed differences among the parental lines for some of the characters studied and confirmed the contrasting features of the testers. Furthermore, the inheritance patterns of the various agronomic traits were determined and the potentials of the parental lines as sources of desirable alleles for okra improvement were documented.

\section{References}

AHIAKPA, J.K. - KALEDZI, P.D. - ADI, E.B. - PEPRAH, S. - DAPAAH, H.K. 2013. Genetic diversity, correlation and path analyses of okra (Abelmoschus spp. (L.) Moench) germplasm collected in Ghana. In International Journal of Development and Sustainability, vol. 2, 2013, no. 2, pp. 1396-1415.

ARORA, D. - JINDAL, S.K. - GHARI, T.R. 2007. Generation mean analysis for earliness related traits in Okra (Abelmoschus esculentus (L). Moench). In Journal Genetics and Breeding, vol. 61, 2007, pp. 1-7. BADU-APRAKU, B. et al. 2015. Heterotic responses among crosses of IITA and CIMMYT early white maize inbred lines under multiple stress environments. In Euphytica, vol. 204, 2015, no. 3, pp. 245262. doi: 10.1007/s10681-015-1506-0.

KEMPTHORNE, O. 1957. An introduction to genetic Statistics. New York : John Wiley and Sons, 1957.

KUMAR, N. 2006. Breeding of Horticultural Crops. New Delhi : New India Publishing, 2006.

KUMAR, S. - DAGNOKO, S. - HAOUGUI, A. - RATNADASS, A. PASTERNAK, D. - KOUAME, C. 2010. Okra (Abelmoschus spp) in West and Central Africa: Potential and progress on its improvement. In African Journal of Agricultural Research, vol. 5, 2010, no. 25, pp. 3590-3598.

NWANGBURUKA, C. C. - DENTON, O.A. - KEHINDE, O.B. - OJO, D.K. - POPOOLA, A.R. 2012. Genetic variability and heritability in cultivated okra [Abelmoschus esculentus (L.) Moench]. In Spanish Journal of Agricultural Research, vol. 10, 2012, no. 1, pp. 123-129.

OYETUDE, O.A. 2015. Genetics and Inter-character Relationships in a Population of Sixteen $\mathrm{F}_{1}$-hybrids of Okra (Abelmoschus esculentus L. (moench)), arising from Biparental crosses. M. Agric. Abeokuta : Thesis, Federal University of Agriculture, 2015.

PRAKASH, M. - KUMAR, M.S. - SARAVANAN, K. - KANNAN, K. GANESAN, J. 2002. Line $\times$ tester analysis in okra. In Annals of Agricultural Research 23: 233-237.

RASHID, M. - CHEEMA, A. A. - ASHRAF, M. 2007. Line $\times$ tester analysis in basmati rice. In Pakistan Journal of Botany, vol. 39, pp. 2035-2042. REDDY, M.T. - BABU, K.H. - GANNESH, M. - BEGUN, H. - DILIPHABU, J. - REDDY, R. S. K. 2013. Gene action and combining ability of yield and its components for late kharif season in okra (Abelmoschus esculentus (L.) Moench). In Chilean Journal of Agricultural Research, vol. 73, 2013, no. 1, pp. 0718-5839.

REWALE, V. S. - BENDALE, V.W. - BHAVE, S. G. - MADAV, R. R. JADHAV, B. B. 2003. Combining ability of yield and yield components in okra. In Journal of Maharashtra Agricultural University, vol. 28, 2003, pp. 244-246.

SHUSMITA, M. - DAS, N.D. 2003. Combining ability studies in okra. In Journal of Interacademicia, vol. 7, 2003, no. 4, pp. 382-387.

SINGH, R.H. - CHOUDHARY, B.D. 1985. Biometrical methods in quantitative genetics analysis. New Delhi : Kalyani Publishing, 1985. WEERASKAR, D. 2006. Genetic analysis of yield and quality parameters in okra (Abelmoschus esculentus (L) Moench). Dharward: M. Agric Thesis, University of Agricultural Science, 2006. 